\title{
중남미 기업의 사회적 책임과 사회개발
}

홍 욱 헌 (위덕대학교 경찰행정학과 교수)

지

\section{목 차}

I. 기업은 사회 개발의 주역인가?

II. 기업의 사회적 책임론

III. 중남미 CSR 현황

$\mathrm{IV}$. 중남미 CSR 활동의 확산 동인

$\mathrm{V}$. 중남미 CSR 사례

$\mathrm{VI}$. 중남미 CSR의 사회개발 효과

VII. 결론

\section{I. 기업은 사회 개발의 주역인가?}

브라질은 기업의 사회적 책임활동 면에서 선진국이다. 2012년 3월 사회적 책임 표준기업활동 지표, SA8000 Standard의 인증을 받은 기업 수를 보면, 브라질은 84개로 세계 6위를, 여기 종사하는 인력 수는 12만6천명으로 4위를 점하고 있다.1) 2005년부터 상파울로 주식거래소에 는 기업의 사회적 책임 지수가 사용되고 있다. Porter와 Kramer에 의하면, ${ }^{2)}$ 기업이 국내외적

1) Social Accountability Accreditation Services, "SA8000 Certified Facilities List," March 31, 2012, http://www.saasaccreditation.org/certfacilitieslist.htm.

2) Michael E. Porter and Mark R. Kramer, "The Big Idea: Creating Shared Value: Rethinking Capitalism," Harvard Business Review, Jan-Feb 2011: 1-17. http://partnership2012.com. 
으로 공정경쟁, 협력업체 및 사회 여러 부문과 동반성장, 인권 존중, 자연환경 보호 등을 적극적 으로 실천하면 모든 사회 부문이 다 같이 발전될 수 있다고 하였다. 하루에 $\$ 2$ 미만으로 살아가 는 빈곤인구가 2009년 10\%를 넘고 있고 빈부격차가 세계에서 가장 심한 나라의 하나이지만,3) 기업의 사회적 책임활동을 기준으로 보면, 브라질은 머지않아 선진적인 공정한 사회가 될 것이 다.

브라질뿐만 아니라 중남미 전체가 기업의 사회적 책임활동 면에서 선진적인 대륙이 될 것 같 다. 2010년 유엔 세계표준기업활동, Global Compact를 준수하겠다고 서명한 중남미 기업 수 는 1,100 개를 넘어 유럽에 이어 두 번째로 많다.4) 서명 기업 수를 기준으로 보면, 브라질은 세 계 4위, 콜롬비아 6 위, 아르헨티나 7 위, 멕시코 18 위 등 세계 상위 20 개국에 4 개국이나 들어 있 다. 2010년 중남미에는 하루 $\$ 1.25$ 이하로 살아가는 인구가 4천5백만으로 전체인구의 $8 \%$ 를 넘 고 있고5) 빈부격차가 심한 지역이지만, 기업의 사회적 책임활동의 확산으로 균형발전이 기대되 고 있다.

과연 기업의 사회적 책임론은 민간기업뿐만 아니라 사회발전의 효과적인 대안인가? 이 글은 중남미에서 상당히 활발하게 진행되고 있는 기업의 사회적 책임활동을 통해 그 시사점을 찾아 보려 한다. 중남미 사례는 다음 네 가지 점에서 의미가 있다. 첫째, 중남미 지역은 동질적인 사 회가 아니지만, 대부분의 국가는 아직 개도국의 위치에 있다. 기업의 사회적 책임활동이 주로 유럽과 북미 지역에서 활발하게 이루어지고 있어, 중남미 사례는 개도국에서도 효과적인 사회 발전 대안인지 검토하게 한다. 둘째, 중남미 대부분의 국가는 도시와 농촌간에, 또는 도시 내 거 주지역별, 토착민과 이주민간에 사회개발이 양극화되어 있어, 기업의 사회적 책임이 사회균형 발전의 동력으로 효과가 있는지 검토하는데 도움이 될 것이다. 셋째, 중남미 지역에서 사회적 책임활동을 선도적으로 하는 기업에는 다국적기업이 주류를 이루고 있어, 외국기업이 이 지역 사회발전의 주도적 역할을 할 수 있을지를 검토할 수 있다. 중남미 지역에는 1990년대 민영화 로 민간 대기업이 크게 증가하였지만 아직은 다국적기업이 사회적 책임활동을 주도하고 있다. 마지막으로 중남미에 최근 우리나라 기업이 눈에 띠게 진출하고 있어 이 지역 기업의 사회적 책 임활동 정보는 한국기업의 경쟁력 확대에도 도움이 될 것이다.

3) World Bank, World Development Indicator 2011, http://data.worldbank.org.

4) Carrie Hall, United Nations Global Compact Annual Review 2010 (UN Global Compact Office, 2011).

5) FAO,"2012 World Hunger and Poverty Facts and Statistics." http://www.worldhunger.org. 
먼저, 중남미 지역에는 기업이 사회적 책임 활동을 어떻게 수행하는가, 어떠한 이유로 기업은 사회적 책임 활동을 하는가, 소비자 또는 일반인들은 기업의 사회적 책임 활동을 어떻게 인식하 는가, 그리고 기업의 사회적 책임 활동은 사회발전에 어떤 효과를 주는가를 검토하겠다. 끝으로 보다 효과적인 사회적 책임활동에 대한 시사점은 무엇인가 순으로 살펴보겠다.

여기에 사용된 자료는 주로 기업가 및 일반인을 상대로 한 설문조사, 국제기관의 통계, 연구 논문 등이다. 기업의 사회적 책임에 관한 자료는 인터넷 상에 공개된 것들이다. 2011년 브라질 상파울로에 위치한 기업의 사회적 책임 비영리법인인 Instituto Ethos와 페루 리마의 Perú 2021의 관계자들과의 면담내용도 참고하였다.

\section{II. 기업의 사회적 책임론}

기업의 사회적 책임(corporate social responsibility, CSR)은 기업양심(corporate conscience), 기업시민상 (corporate citizenship), 사회활동(social performance), 지속가 능책임기업 (sustainable responsible business), 또는 책임기업 (responsible business) 등 으로 표현되고 있다. 기업의 사회적 책임이란 용어는 1960년대 후반부터 사용되었으나 1990년 대 후반 이후 구체적 내용이 다양화 되었다. ${ }^{6)}$ 가장 명확한 정의 중 하나인 국제연합(UN)의 Global Compact가 제시한 기업의 사회적 책임은 네 분야에서 열 가지 원칙으로 구성되어 있 다. 인권 분야 2 개 원칙, 노동 분야 3 개 원칙, 환경 분야 3 개 원칙 그리고 반부패 분야 1 개 원칙 등이며, 기업은 이 원칙들을 준수해야 최소한의 사회적 책임을 다하는 기업으로 인정받을 수 있 다. 7)

6) R. Edward Freeman, Strategic Management: A Stakeholder Approach (Cambridge University Press, 2010); 오삼교, 이남섭, 최윤국, 홍욱헌, 『중남미진출 한국기업의 사회적 공헌 제고방안연구』(KIEP, 2011), 24-43쪽.

7) 인권 분야: 1) 기업은 국제적으로 선언된 기본 인권 보호를 존중하고 실천해야 한다. 2) 기업은 인권 학대에 간접 적으로 묵인하거나 연루되지 않도록 주의한다. 노동 분야: 3) 기업은 결사의 자유와 단체협상권을 실질적으로 인 정하고 준수한다. 4) 기업은 모든 형태의 강제노동을 제거해야 한다. 5) 기업은 미성년자 노동을 실질적으로 철폐 해야 한다. 6) 기업은 고용과 업무에 차별을 해서는 안 된다. 환경 분야: 7) 기업은 환경 변경 시 사전적 영향평가 와 신중하게 접근해야 한다. 8) 기업은 광범위한 환경보호를 추진하는데 주도적 역할을 한다. 9) 기업은 환경친화 적 기술을 개발 및 확산하는데 적극적 노력을 해야 한다. 반 부패 분야: 10) 기업은 직무상 부당이익 및 뇌물의 추 구와 제공 추구 등 모든 형태의 부패를 거부해야 한다. Carrie Hall, United Nations Global Compact Annual Review 2010 (2011) http://www.unglobalcompact.org/docs/news_events. 
$\mathrm{CSR}$ 활동의 적극성 정도에 대해서도 여러가지 단계들이 제시되고 있다. Carroll은 CSR을 경제적, 법적, 윤리적 및 자선적 형태로 나누고 이에 대한 수용 정도를 기준으로 반동적, 방어 적, 순응적 그리고 적극적 단계로 구분하고 있다. ${ }^{8)}$ Porter와 Kramer에 의하면, "기업의 경쟁 력과 수익은 사회적 발전 없이는 불가능하다" 는 명제를 기업인이 적극적으로 수용할 경우 사회 와 동반성장할 수 있는 기업의 공동선(corporate shared value, CSV) 단계로 발전할 수 있 다. ${ }^{9)}$

기업의 사회적 책임론은 적어도 세 가지 점에서 이전의 기업활동과 다르다. 첫째, 기업활동 전반에 걸쳐 자율적으로 사회적 책임을 수행해야 한다. 복지국가나 전통적인 자본주의에서 기 업은 공정한 경쟁을 법으로 규제를 했지만, 사회적 책임론에서는 인권, 노동, 환경, 및 청렴성 등 여러 분야의 법적 규제를 자율적으로 준수하여 기업윤리로 승화시켜야 한다. 둘째, 기업의 자연파괴나 공해 배출 등 부정적 외부효과를 기업이 직접 해소해야 한다. 과거 기업의 부정적 외부효과를 정부나 지역사회가 감수해야 했지만 사회적 책임론에서는 기업이 비용을 지불해야 한다. 셋째, 기업은 소비자, 협력업체 등 일련의 기업활동 관련 당사자들의 사회문제 해결에 참 여해야 한다. 과거에도 기업은 메세나(Mecenat) 운동을 통해 사회공헌을 하였지만, 사회전체 의 개발에 적극적으로 투자하여 잠재시장을 개발해야 할 의무가 생겼다. 일반적으로 사회문제 는 정부가 해결해야할 영역이었으나, 공공영역과 민간기업 영역이 모호해짐에 따라 기업도 사 회개발에 적극적으로 투자해야할 필요가 있다는 것이다.

요약하면, 기업이 인적 및 물적 자원을 활용하는 기업활동 과정에서 나타날 수 있는 부정적 외부효과, 즉 노동착취, 인권 침해, 자연파괴, 공해 등을 적정하게 변제하는 경우 최소한 사회적 책임을 다한 것으로 볼 수 있다. 기업이 부정적 외부효과를 방치하면 사회적 책임을 다했다고 할 수 없다. 만약 기업이 부정적 외부효과를 보상하고 또한 사회개발에도 투자하면 우수한 사회 적 책임기업으로 평가될 수 있다.

8) Archie B. Carroll, "Corporate Social Responsibility: Evolution of a Definitional Construct," Business \& Society, 38, 3 (1999): 269-295. http://uga.academia.edu.

9) Porter and Kramer, op. cit. 


\section{III 중남미 CSR 현황}

\section{CSR 활동 크게 확산}

최근 CSR 관련 세계표준기업활동 보고서에 의하면, 중남미에는 CSR이 기업의, 특히 대기업 의 보편적 활동으로 확산되고 있다. 예를 들면, 2011년 지속가능 발전에 역점을 둔 GRI 보고서 를 채택한 중남미 국가로는 브라질이 88개, 멕시코가 66개, 칠레가 27개 업체다.10) 2006년 GRI 보고서를 채택한 기관이 중남미에서 총 27 개에 불과하였던 것에 비하면 크게 확산되었다. 현재 세계적으로 6,500 여개 기관이 CSR 보고서로 GRI를 사용하고 있다. UN의 CSR운동 Global Compact의 경우, 2000년 발족 당시 브라질과 멕시코 업체들만 참가하였지만, 2010년 에는 중남미 대부분의 국가의 기업들이 참가하고 있다. CSR 표준보고서를 사용한다는 것은 기 업이 CSR의 중요성을 수용하고 이에 대한 준비를 많이 하는 것을 뜻하며, 결과적으로 CSR 활 동을 잘하고 있다는 의미다.

중남미 국별로 보면 브라질의 기업이 사회적 책임활동에 가장 적극적이다. Google 검색창을 통해 나타난 중남미 국별 CSR 활동 수준을 조사한 연구에 의하면,11) 브라질이 가장 높으며 이 어서 멕시코와 아르헨티나 순이다. 2011년 중남미 21개 CSR 진흥 단체협회인 Red Forum Empressa는 3,400여개의 후원사가 가입하고 있다. Red Forum Empressa가 17개 중남미 국가의 기업 경영자 1,279 명을 대상으로 한 인터넷 설문 조사 결과에 의하면,12) 조사 참여 기업 의 $55 \%$ 는 명문화 된 CSR 정책을 갖고 있으며, 응답기업의 $47 \%$ 는 GRI를 사용하고 있다. 중남 미 지역에서 CSR이 크게 확산되었다는 것을 일반인들도 공감하고 있다. 2011년 설문조사를 보 면, 지난 2년간 국내 활동하고 있는 기업들의 CSR 활동에 어떤 변화가 있었다고 생각하는가에 대해, 소비자 응답자 중 $55 \%$ 는 진전이 있었다고 말하며, $31 \%$ 는 변화가 없다고, $8 \%$ 는 악화되었 다고, $6 \%$ 는 모른다고 답하였다.

10) Global Reporting Initiative, GRI: Inside [and] out, Global Reporting Initiative Sustainability Report 2010/11. https://www.globalreporting.org.

11) Jose Mauricio Ballivian, "Corporate Social Responsibility (CSR) Activity in Latin America," Dec. 2009. http://quest.uprrp.edu/7quest/papers/Jose\%20Mauricio\%20Ballivian.pdf.

12) Yanina Kowszyk, Andres Covarrubias, and Laura Garcia, The state of Corporate Social Responsibility in Latin America, (Red Forum Empresa, 2011. www.empresa.org. 


\section{2. 다국적기업과 대기업이 주도}

중남미에서 CSR 활동에 적극적인 기업은 다국적기업과 대기업들이 주종을 이루고 있으며, 자원개발이나 공해유발 기업 중에는 일부 중소기업도 참여하고 있다. Global Compact 2010 년 통계에 의하면, 대기업 및 주식공개기업이 중소기업보다 인력 및 재정 면에서 높은 수준의 사회적 책임 활동을 수행하고 있다. CSR 참가 기업의 반 이상이 250 인 이상의 대기업이다.

$\mathrm{CSR}$ 활동에 가장 앞선 기업은 어떤 것인가란 질문에 기업경영자와 소비자 전체 응답자 중 $62 \%$ 는 다국적기업 회사라고 답하고 있으며, 국내기업이라고 답한 응답자는 $26 \%$ 에 불과하 다.13) 그러나, 국내 기업도 CSR 활동이 다국적기업에 비해 빠르게 확산되고 있다고 소비자들 은 보고 있다. 지난 2 년간 어떤 기업이 CSR 활동에 개선이 있었는지에 대한 질문에 국내 기업 이 개선되었다는 응답자는 $72 \%$ 이며, 다국적기업이 개선되었다는 응답자는 $64 \%$ 에 머무르고 있 다.

중남미 중소기업은 전체 기업 수에서 $90 \%$ 를 차지하고 도시근로자의 $56 \%$ 가 종사하고 있으 나,14) 공통적으로 미등록업체, 세금탈세, 부패 등으로 얼룩져 있다. 중소기업은 대부분 투자자 와 주인이 같은 경우가 많아 윤리강령 같은 것이 없었다. ${ }^{15)}$ 반면에, 중소기업이 대기업이나 다 국적기업의 협력회사일 경우 윤리강령을 채택하는 경우가 많다. 중남미 중소기업과 유럽 중소 기업간의 CSR 비교 연구에 의하면, ${ }^{16)}$ 전자의 기업이 후자의 기업보다 더 많은 사회적 책임 활 동을 하는 것으로 나타났다. 양자 모두 윤리적 및 종교적 이유로 CSR을 하지만, 중남미 중소기 업이 지역사회로부터 더 많은 CSR 요구를 받고 있는 것으로 나타났다. 유럽에서 환경 분야 $\mathrm{CSR}$ 은 중남미보다 휠씬 자율적으로 회사의 이미지 개선을 위해 이루어진다. 유럽의 중소기업 이 CSR에 참여하지 않는 이유는 시간 때문이라는 것이 다수이나, 중남미에서는 재원 부족이라 는 것이 주 이유이다.

브라질의 경우 중소기업도 CSR에 대한 관심은 많은 편이다. 2006년 브라질 여론조사 기관인

13) Kowszyk, Covarrubias, and Garcia, op. cit.

14) World Bank, Informality in Latin America, (2008). http://www.ethicalcorp.com

15) Maria Cecilia Coutinho de Arruda, "Ethics and Corporate Social Responsibility in Latin American Small and Medium Sized Enterprises: Challenging Development,??African Journal of Business Ethics, 4 (2009), pp. 37-47. http://www.ajobe.org.

16) Antonio Vives, "The Role of Corporate Social Responsibility in Latin America: Is It Different From That in Europe?,"Paper presented at the Iberoamerican Workshop on Corporate Social Responsibility, Fundación Carolina of Spain, Cartagena de Indias, Colombia, June 2006. http://ebookbrowse.com/gdoc.php?id=337734724\&url=ff8eca2437fb7952b5dd51d118bda097 
IPEA가 국내 기업 1 만여개를 상대로 한 조사에 의하면, $69 \%$ 의 기업이 사회개발에 참여한다고 대답하였다. ${ }^{17)}$ 대기업의 $94 \%$, 그리고 500 명 이하의 중기업의 $87 \%$ 가 한 가지 이상의 CSR 활 동 과제를 갖고 있었다. 100 명 이하의 소기업의 $75 \%$ 와 10 명 이하의 소기업의 $66 \%$ 도 사회활동 을 한다고 보고하였다. 업종별로는 의약품 제조업체, 화학제품업체, 가죽가공, 종이 제조업체 등의 $90 \%$ 이상이 환경보호 프로그램을 가지고 있다.

\section{3. 기업가와 소비자의 CSR 인식차가 크다}

기업경영자가 중점을 두고 있는 CSR 활동과 일반 소비자가 생각하는 CSR 활동간에는 아직 큰 괴리가 있다. 2011년 기업경영인의 73\%는 CSR 활동이 적극적으로 이루어지고 있다고 보지 만, 소비자는 $54 \%$ 만이 그렇게 평가하고 있다. 어떤 분야의 기업이 CSR을 가장 적극적으로 추 진하고 있는가에 대해서도 기업경영자와 소비자간 응답이 상당히 다르다. 예를 들면, 기업경영 인은 백화점(81\%), 농업, 수렵 및 어업(79\%), 건축(78\%), 제조업(78\%), 수자원(77\%), 에너지 (76\%) 순으로 답하고 있다. 18$)$ 반면, 소비자의 경우, 농업, 수렵 및 어업(60\%), 수송 및 창고 (58\%), 무역 $(58 \%)$, 제조업(57\%), 건설 $(56 \%)$, 통신(56\%), 광업(56\%) 및 에너지(56\%) 순이다. 백화점은 경영인에게는 $\mathrm{CSR}$ 이 가장 적극적으로 추진되고 있지만, 소비자에게는 가장 하위에 (49\%) 위치하고 있다.

$\mathrm{CSR}$ 의 발전을 저해하는 가장 큰 요소로, 기업경영인의 $30 \%$ 는 CSR에 대한 일반인의 태도라 고 답하고 있다. $23 \%$ 는 민간기업에 대한 불신, $19 \%$ 는 법적 환경, $13 \%$ 는 세금제도를 꼽고 있다. 반면, 소비자의 $30 \%$ 는 민간기업에 대한 불신을, 다음으로 $25 \%$ 가 법적 환경, $18 \%$ 가 CSR에 대 한 일반인의 태도, $3 \%$ 가 세금제도를 들고 있다. 노동 규제의 경우, 기업경영인의 $51 \%$ 와 소비자 의 $71 \%$ 가 더 강화해야 된다고 말하고 있다. 기업경영인의 $19 \%$ 는 노동규제가 줄어들어야 한다 고 하며 $27 \%$ 는 현행대로 유지해야 한다고 했다.

기업경영자와 일반 소비자간의 인식괴리는 정보의 차이에서 일어나는 정상적인 현상이기도 하다. 그러나 중남미 사람들은 민간기업에 대한 불신이 전통적으로 매우 높은 편이다. Latinobarómetro가 2000년에서 2011년까지 조사한 바에 의하면, 거의 매년 단지 $42 \%$ 가 민 간기업에 대한 약간 또는 많은 신뢰를 하고 있다. 민간기업은 국내 주요 15 개 공익기관 중 8 위 를 차지하고 있다. ${ }^{19)}$ 그러나 기업가나 소비자도 환경 보호에 대해서는 공감대를 갖고 있다. 환

17) IPEA, "A Iniciativa Privada e o Espírito Público: A evolucão da acão social das empresas privadas no Brasil," 2006. http://www.ipea.gov.br/acaosocial//MG/pdt/doc-28.pdf.

18) Kowszyk, Covarrubias, and Garcia, op. cit.

19) Latinobarómetro, Latinobarómetro 2011 Annual Report, 2011. www.latinobarometro.org. 
경규제를 강화해야 한다고 생각하는 응답자는 기업경영인의 $83 \%$ 와 소비자의 $92 \%$ 가 동의하고 있다. ${ }^{20)}$ 자연보호를 준수하는 기업의 재화와 서비스가 값이 비싸더라도 구매하겠다는 소비자는 95\%에 달하고 있다. 이들 중 6-20\% 까지 더 비싸게 지불해도 환경친화적 제품을 구매하겠다 는 소비자가 $66 \%$ 에 달하고 있다.

노동 규제의 경우, 기업경영인의 $51 \%$, 그리고 소비자의 $71 \%$ 가 더 강화해야 된다고 말하고 있 다. 노동규제의 경우, 기업경영인의 $19 \%$ 는 노동규제가 줄어들어야 한다고 하며, $27 \%$ 는 현행대 로 유지해야 한다고 했다.

\section{4. 소비자를 중시}

$\mathrm{SA} 8000$ 인증을 받은 중남미 기업은 사회적 책임활동 전 분야에 고루 적극적이다. 기업이 홈 페이지에 보여주는 지역사회에 대한 CSR 활동을 보면, 전반적으로 저소득자, 토착민, 아프리카 계 주민, 장애자, 농민 및 토착인 등의 교육, 의료 및 소득 증대에 관심을 집중하고 있다. CSR 을 추진하는 기업에서도 부패와 인권에 대한 철저한 관리는 이루어지지 않고 있다. 2011년 조사 대상 기업의 대부분은 고용과 업무에서 차별철폐와 기회균등 정책을 추진하고 있다. 그러나 주 기적으로 인권영향 평가를 시행하는 곳은 $20 \%$ 미만이었으며, 부패사례를 보고하는 기업도 $30 \%$ 미만이었다. 반부패 부문에 있어서 중소기업은 대기업에 비해 실행 정도가 매우 낮다.

CSR 활동 수준에 대한 주관적 평가는 부문별로 다양하다. 2011년 설문조사를 보면, 기업경영 인들은 CSR 활동 부문별로 소비자와의 관계, 노동자와의 관계, 지역사회와의 관계, 환경, 정책 결정 및 투명성 순으로 중시하고 있는 것으로 나타났다. ${ }^{21}$ 기업경영인의 $80 \%$ 는 소비자에 대한 책임을 잘 수행하고 있다고 보고 있으며, 정책결정과 투명성 분야에는 $69 \%$ 만이 동의하고 있다. 반면 일반인들은 소비자와의 관계, 정책결정 및 투명성, 지역사회와 관계, 노동자와 관계, 그리 고 환경 순으로 잘하고 있다고 답했다. 일반인들 $56 \%$ 가 기업의 소비자에 대한 책임을 잘하고 있다고 평가하였으며, 정책결정과 투명성 분야에는 $55 \%$ 가, 환경에는 $50 \%$ 만이 동의하고 있다.

2001년 브라질 판매 및 홍보협회(ADVE) 조사에 의하면, 브라질 기업의 경우 $74 \%$ 가 교육관

20) Kowszyk, Covarrubias, and Garcia, op. cit.

21) Kowszyk, Covarrubias, and Garcia, op. cit.

22) Francisco P. de Melo Neto and César Froes, Gestão da responsabilidade social corporativa: O caso brasileiro. Da filantropia tradicional á filantropia do alto rendimento e ao empreendedorismo social (Rio de Janeiro: Qualitymark, 2001). 
련 CSR에 제일 우선순위를 두고 있으며 다음으로 환경 문제(37\%)와 건강 문제(35\%)에 두고 있 다고 했다. ${ }^{22)}$ 2004년 브라질 기업의 사회투자총액은 US\$ 23.5억으로 이는 GDP의 $0.27 \%$ 에 해당한다. CSR 활동 중에서 가장 관심을 두는 곳은 식품이며, 다음으로 사회복지, 건강 및 교육 순이었다.

브라질 소비자들의 CSR 인식은 2000년대 초반 이후 변화하고 있다. 브라질 사회단체인 Instituto Akatu가 2001년에 조사한 브라질 소비자의 CSR 인식 조사에 의하면, $35 \%$ 가 기업 은 고용과 수익 추구 이외의 활동을 해야 한다고 답하고 있다. ${ }^{23)}$ 즉 보다 좋은 사회를 위해 기 업은 세금납부, 법 존중 등 윤리적 기준을 준수해야 한다고 한다. 2005 년 조사에서는 $44 \%$ 로 늘 어났다. $88 \%$ 의 응답자는 정부가 주도하는 범죄, 빈곤 및 낮은 교육열 등의 문제를 처리하는데 기업이 참여해야 한다고 했다. 소비자의 절대 다수(82\%)는 기업 제품 품질을 가장 중요한 CSR 로 보고 있다.

\section{5. 비영리사회단체 및 지방정부간 협력}

중남미 지역의 기업들이 CSR을 추진하는 방식으로는 CSR 추진 비영리사회단체와 협력하는 경우가 많다. 기업이 독자적으로 CSR 전담부서를 설치하여 담당하게 하거나 CSR 재단을 독립 기관으로 만들어 추진하기도 하지만, 지역사회 개발에 투자할 경우 외부 CSR 관련 전문기관과 협력하고 있다. 농촌개발이나 지역사회 기간시설 개발에 참여하는 경우 지방정부와 긴밀한 관 계를 유지하고 있다. 예를 들면, 페루의 Antamina 광업체는 지속가능경영을 표방하고 있으며 지역사회와 정부들과 긴밀한 관계를 중요시하고 있다. ${ }^{24)}$ 도로 포장, 전기선, 광전선 등을 철관 을 따라 가설하여 인근 지역의 전기 및 통신을 가능케 하였다. 생산기술, 건강, 교육 등 분야에 관련 주 및 군에 지원하고 있다. Antamina 광업체는 비영리법인 안카쉬법인(Asociación Áncash)을 설립하여 CSR을 대행하게 하며 광산 인근 지역사회의 발전에도 도움이 된다는 것 을 증명하기 위해 여러 가지 형태의 장단기 사업을 투명하게 추진하고 있다. Antamina 광업은 페루 정부의 요청에 따라 2007년부터 Antamina 광업기금(Antamina Mining Fund, AMF) 을 운용하고 있다. 이 기금은 UN의 새천년발전목표를 추구하는데 사용하기로 되어 있다. AMF 는 Áncash 주민들의 생활향상을 위한 투자자금으로 사용되며 자발적 기부에 의해 조성되고 있

23) Instituto Akatu, "Consumers Perceptions in Brazil" (2001); and "Corporate Social Responsibility Perception of the Brazilian Consumer" (2005). http://www.akatu. org.br.

24) 주요 사례는 오삼교, 이남섭, 최윤국, 홍욱헌, 앞의 책 참조. 
다. $\mathrm{AMF}$ 는 시민단체와 연합하여 자금운영을 하고 있으며, 지역주민과 관련 정부의 참여를 제 도화하고 있다. 2011년 5월말까지, AMF는 US\$262.9백만을 확보하였다. 이 중에서 US\$ 203.7백만이 사용되었다.

아르헨티나, 멕시코 및 브라질에도 기업은 외부기관과 연계하여 CSR 활동을 추진하고 있다. 2005년 153개 대기업을 상대로 UNDESA가 조사한 바에 의하면, 아르헨티나 대부분의 대기업 들은 사회단체에 현금 또는 현물을 기부하고 있다. $25 \%$ 는 자체의 재단을 설립하여 초등 및 유 아교육 지원, 빈곤프로그램, 건강 증진 등에 참여하고 있다. 베네수엘라의 경우, 국영석유회사 $\mathrm{PDVSA}$ 는 중앙정부의 지도 아래 지역사회의 교육, 의료 및 주택 개발 등에 책임지고 있으며 사 회발전기금을 적립하고 있다.

\section{$\mathrm{IV}$. 중남미 CSR 활동의 확산 동인}

Global Compact 2008 보고서에서 일반적으로 기업이 CSR에 참여하는 이유로는 크게 1) 환경 및 사회 문제가 기업경영의 핵심과제로 부상, 2) 기업의 신뢰 제고, 3) 사회안정과 발전이 기업발전이라는 공동선의 가치, 4) 다른 기관과 협력 용이, 5) 인도적 관심을 실현할 수 있기 때 문으로 열거하고 있다. ${ }^{25)}$ Porter \& Kramer는 CSR이 기업의 경쟁력을 약화시키는 비용, 제 약 또는 단순한 자선이 아니라 새로운 기회, 혁신 및 경쟁전략일 수 있다고 주장하였다. ${ }^{26)}$

중남미에서 CSR이 확산되고 있는 요인에 대해서는 나라마다 다르지만 크게 세 가지를 들 수 있다. ${ }^{27)}$ 먼저 기업경영자 중에서 CSR 활동이 기업의 비용 증가가 아니라 수익 증대에도 도움 이 된다는 인식이 확산되고 있다. 이 지역 대기업이나 다국적 기업들이 유럽과 북미 지역 등과 거래를 늘이면서 국제기업활동 표준을 지키는 것이 시장확대에 도움이 된다고 인식하였다. 응 답기업의 $70 \%$ 이상의 최고경영자가 사회적 책임활동의 정책 및 전략 개발에 적극적으로 관여 하고 있다고 답하고 있다. 주식 공개기업의 약 $60 \%$ 응답자는 이사회가 사회적 책임활동의 정책 및 전략 개발에 적극적으로 관여하고 있다고 답했다. CSR 활동은 지역사회, 투자자의 요구뿐만

25) Carrie Hall, United Nations Global Compact 2008 Annual Review, 2009.

26) Porter \& Kramer, 2006, p. 80.

27) Roberto Gutirrez and Audra Jones, "Corporate Social Responsibility in Latin America: An Overview of Its Characteristics and Effects on Local Communities," 2005. http://ssrn.com/abstract=1018674 
아니라 시장확대의 효과가 크기 때문이다. 기업이 사회적 역할을 확대해 언론매체의 관심을 살 수도 있다.

둘째, 소비자를 포함한 이해당사자 그리고 CSR 확산 사회단체들의 압력도 크게 증가했다. 2011년 소비자의 경우, 자연보호 CSR을 준수하는 기업이 생산하는 재화를 값이 비싸더라도 구 매하겠는가에 대한 질문에 95\% 이상의 응답자는 긍정적으로 답하고 있다. 6-20\% 까지 비싸게 주더라도 환경친화적 제품을 구매하겠다는 소비자가 $66 \%$ 에 달하고 있다.

중남미에서는 $\mathrm{CSR}$ 장려를 위한 비영리 단체들이 비교적 잘 확립되어 있다. $\mathrm{OECD}, \mathrm{IDB}$, $\mathrm{OAS}$, 사단법인, 국제 NGOs, 다국적 기업 본부 등 외부 기관들이 적극적으로 재정지원도 하고 있다. 이들 국제기구들은 국내의 사회단체, 정부, 학계 및 민간기업들과 연계하여 활동하고 있 다. CSR 확산을 주도하는 국내외 단체로는 1988년 설립된 멕시코의 Centro Mexicano para la Filantropa A.C.(CEMEFI), 1994년 설립된 Perú 2021, 1997년 코스타리카의 Asociación de Empresarios para el Desarrollo(AED), 1998년의 브라질의 Instituto Ethos와 칠레의 PROhumana 등을 들 수 있다. 2003년 중남미를 중심으로 국제적 CSR 기구인 Red Puentes Internacional 등이 결성되었다. 2011년 중남미 18개국의 CSR 진흥 비영리 사회단체 21개 협 회인 Red Forum Empresa는 3,400여개의 회원을 가지고 있다. 이들 단체들은 기업들의 $\mathrm{CSR}$ 활동이 비용이 아니라 수익 개선에 도움을 준다는 점을 강조하였으며 CSR 활동이 단순한 자선 활동뿐만 아니라 기업시민으로의 의무와 권리, 사회투자 등을 장려하였다.

셋째, 1980년대 외채위기 이후 정부의 복지활동이 크게 줄었고 또한 사회기간시설에 대한 투 자도 줄어든 데 기인한다. 정부를 대신해 기업이 지역사회 공공재 개발에 참여하게 되었다. 이 러한 현상은 1980 년대까지 정부주도의 수입대체산업화에서 1990년대 민영화 및 시장경제로 이 행하면서 정부의 사회 후원체계가 무너져 기업이 사회적 역할을 담당하게 된 점도 크게 작용하 였다. 민영화 된 공기업들이 과거의 공익 활동 전통을 유지하여 사회개발 활동을 하고 있다. 또 한 범죄, 실업, 빈곤 등이 심각하면 민간기업이 기업활동을 효과적으로 수행할 수 없다는 인식 도 크게 확산되었기 때문이다.

$\mathrm{CSR}$ 의 발전을 저해하는 가장 큰 요소로 기업경영인의 $30 \%$ 는 CSR에 대한 일반인의 태도라 고 답하고 있다. $23 \%$ 는 민간기업에 대한 불신, $19 \%$ 는 법적 환경, $13 \%$ 는 세금제도를 꼽고 있다. 반면, 소비자의 $30 \%$ 는 민간기업에 대한 불신을, 다음으로 $25 \%$ 가 법적 환경, $18 \%$ 가 CSR에 대 한 일반인의 태도, $3 \%$ 가 세금제도를 들고 있다. 


\section{V. 중남미 CSR 사례}

중남미에서 사회적 책임을 적극적으로 추진하는 업체는 주로 대기업과 이 지역에 진출한 다국 적기업이다. 이들 기업은 사회적 책임을 경영전략으로 명시하고 지속적 과제로 추진하며 경영 인과 구성원이 공유하도록 문서화하고 있다. CSR 활동은 전담부서가 있거나, 별도의 재단을 설 립하거나 또는 외부의 사회단체와 협력하고 있다. 주요 활동 내용은 자선에서 지역개발까지 다 양하다. 예를 들면, 페루의 자원개발업체 Antamina와 Camisea 등은 지역사회의 기간시설을 건설하였고 지역사회 개발을 위해 매년 일정액을 출연하고 있다. 기업의 CSR 활동 사례는 각 기업의 홈페이지에 공개되고 있으며 거의 모든 것이 성공사례 감이다. 여기서는 몇 가지 특이한 사례만 간단히 살펴보겠다.

기업의 사회적 책임활동은 중앙정부 및 지방정부와 협력하여 이루어지고 있다. 예를 들면, 브 라질의 반관-반민기업 Petrobrs는 2003년부터 정부가 추진한 빈곤제로(Fome Zero) 사업에 재정적 지원을 담당하고 있다. 이 사업의 일환인 가족현금지원(Bolsa Familia)은 매달 11백만 명에게 월 $\$ 44$ 를 지불하는 대규모 사업이다. 베네수엘라의 석유공기업 PDVSA는 강제적으로 사회개발기금을 운영하며 지역개발, 주택건설, 교육 등에 참여하고 있다.

농촌 또는 벽지의 특산품의 개발을 도와 지역사회 소득증대를 꾀하는 사업도 눈에 띠게 증가 했다. 예를 들면, 브라질의 Natura Cosmticos는 아마존 지역의 토착민들이 생산한 재료를 사 용해 화장품을 제조하고 있다. 토착민 40만명 정도의 여자에게 일거리를 제공하고 있다.

PepsiCo Perú 경우 2008년 국제감자센터(Centro Internacional de la Papa, CIP), 그리 고 페루의 비영리단체인 생활개선(FOVIDA)과 CAPAC Perú 등과 협력하여 토착감자를 상품 으로 개발하는 안데스감자운동(Iniciativa Papas Andinas, IPA)을 추진하였다. 안데스 산맥 지역은 4천여 종의 토착감자를 재배하는 감자 원산지이다. 이 지역 농민들은 여러 종류의 양질 의 감자를 재배하고 있지만 소득향상으로 연결하지 못했다. 안데스 고원지대의 감자농가는 페 루에서 가장 높은 빈곤, 문맹 및 영양실조를 경험하고 있다. IPA에 동참하고 있는 PepsiCo Perú는 300여 토착감자 농가와 일정량의 생산량을 구매, 대금의 조기 지불, 일정의 이윤 보장 등을 조건으로 계약재배를 약정하였다. CAPAC Perú는 감자의 종류와 등급을 인증하는 "나의 감자 : 엄선 및 등급화 (Mi Papa: Seleccionada \& Clasificada)” 상표를 개발했다. 또한 씨감 자를 개발하고 생산성을 향상시켜 상품의 질을 향상시키고 있다. 리마의 일부 요리학원과 연계 
하여 감자 요리를 개발했다.

정부의 사유재산 몰수 압력을 피하기 위해 사회적 책임 활동을 시작해 성공한 사례도 있다. 예를 들면, 사탕수수 럼을 만드는 베네수엘라의 농장인 Sanata Teresa는 정부의 토지개혁 정 책으로 자산 몰수의 위협을 받자 알카트라츠 사업(Proyecto Alcatraz)을 2003년 시작하여 농 장을 범죄자 재활에 활용하였다. ${ }^{28)}$ 200년 이상의 전통을 갖고 있는 Santa Teresas 농장주 및 최고경영자인 Alberto Vollmer는 "기업이 잘하면 주변 마을도 성공한다"는 생각에서 지역사 회의 청소년 범죄자들이 감옥에 가는 대신 농장에서 3 개월 일하면서, 사회교육 프로그램과 럭 비를 포함한 스포츠 팀 활동에 참석하도록 하였다. 스포츠 활동을 통해 에너지 방출과 일종의 공동체 의식을 키우기 위한 것이었다. Revenga군 지역기관들도 Vollmer의 재활프로그램을 지지하였으며, 2003년에서 2006년까지 이 지역의 범죄자 수는 76\%가 줄었다. Santa Teresa 농장은 약 300 여명의 범법자들을 재활시키고 있다.

파산위기에서 직원복리를 증진시키고 협력업체와도 동반성장을 시도해 성공한 사례도 있다. Chiquita는 2002년 3월 법정관리 파산위기에서 투명경영, 최저임금 및 작업환경 등의 국제노 동기준을 준수하고 협력업체와 동반성장을 주도하였다. ${ }^{29)}$ 바나나 상표로 유명한 Chiquita는 17,000 여명의 직원을 중앙 및 남아메리카에 고용하고 있다. Chiquita는 2006년 ACCA(Association of Chartered Certified Accountants)가 선정한 최고의 CSR 기업의 하 나로 선정되었다. Chiquita는 직원 1천여명을 면담한 뒤에 행동강령을 채택하였다.

콜롬비아의 야외활동 의류업체 Patagonia, 페루의 관광여행업체 Inkaterra, 멕시코의 Walmart, 칠레의 철강업체 Gerdau AZA, 브라질의 Votorantim 등은 환경보호 공해 축소 등 에 적극적으로 참여하고 있다. 예를 들면, Patagonia는 스위스의 푸른 신호등 표준(bluesign) 을 채택하여 제품생산 전 과정에 걸쳐 자원 절약과 공해물질 제거 등 적극적인 노력을 기울이고 있다. Patagonia는 물을 많이 소비하면 할수록 많은 주거를 파괴한다는 구호 아래 식수자원 보 호운동을 이끌고 있다. Patagonia는 협력업체가 일정수준의 환경 및 사회조건을 충족하도록 도와주고 있다.

28) Greg Morsbach, "A Very Different Alcatraz," BBC News, 17 April 2006. http://news.bbc.co.uk/2; www.proyectoalcatraz.org.

29) Marina Prieto-Carron, "Corporate Social Responsibility in Latin America: Chiquita, Women Banana Workers and Structural Inequalities," Dec. 2009. http://www.siyanda.org. 


\section{VI. 중남미 CSR의 사회개발 효과}

2010년대 중남미에는 사회적 책임을 추구한 기업의 수가 크게 늘어났을 뿐 아니라 이에 대한 기업가와 일반인의 인식도 많이 바뀌었다. 대부분의 나라에서 기업의 사회적 책임활동 확산은 정부의 강제에 의해서가 아니라 국내외 기업환경 변화에 자발적으로 적응한 결과이다. 이제 10 여년의 기간이 지난 시점이라 중남미는 사회적 책임 활동이 사회개발의 원동력이 되었는지 점 검할 수 있는 실험장이다.

기업의 사회적 책임활동이 사회발전에 긍정적인 영향을 줄 수 있다는 근거는 크게 두 가지이 다. 첫째, 기업이 자연자원과 인력을 사용하는 과정에서 생기는 부정적 외부효과를 기업 스스로 해결함으로써 기업은 자신의 공익성을 높일 수 있으며 사회와 호혜적 발전을 증진시킬 수 있다. 둘째, 사회발전은 과거에는 정부의 독점적 공공활동으로 인식되었지만, 지금은 공공영역의 경 계가 모호하여 기업이 참여함으로써 보다 효율적 사회발전을 도모할 수 있다는 것이다. 특히 기 업 활동의 근거지인 지역사회의 공공재화와 서비스를 정부를 대신하여 효과적으로 제공할 수 있다.

반면에 기업의 사회적 책임활동이 사회발전에 효과적이지 못하다는 근거는 크게 두 가지이다. 첫째, 기업이 사회발전에 참여하는 것은 추가 비용의 발생을 가져오며 본래의 목적인 최저의 비 용으로 최고 품질의 재화와 서비스를 생산하는 것을 가로막아 장기적으로 보면 기업활동을 위 축시키는 결과를 가져온다. 둘째, 기업의 역할이 사회적 개발까지 확대되면 사회적 견제와 균형 이 깨어져서 기업권력의 남용현상이 나타날 수 있다.

1990년대 국가가 민영화 및 시장경제 도입을 이행할 때 대부분의 중남미 국가에서 보여 주었 던 반대운동은 2000 년대 기업의 사회적 책임 확산과정에서는 볼 수 없다. 시장경제 이행기에 나타난 기업가와 일반인간의 첨예한 인식 차이도 CSR 확산에는 보이지 않고 있다. 일반인과 기 업가는 다 같이 CSR에 호의적이며, 오히려 일반인이 CSR을 더 적극적으로 추진할 것을 주문 하고 있다. 2006년 우루과이에서 조사한 바에 의하면,30) 지역개발, 빈부격차, 환경보호 등은 기업과 정부가 함께 풀어나가야 한다는 응답자가 다수를 차지하고 있다. 때문에 CSR은 모든 기 업의 표준 활동으로 보편화될 가능성이 높다. 실제 CSR은 모든 기업체와 사회기관의 공통된 윤 리로 정착되는 추세이다. 
중남미에서 CSR의 사회개발 효과가 성공적이었다고 평가하기는 아직 어렵다. 개별기업체의 $\mathrm{CSR}$ 사례를 보면 부분적으로 매우 성공적이다. 브라질 정부와 Petrobras가 협력하여 수행한 빈곤제로 활동은 여러 가지 면에서 성공적인 사회개발 사례다. 그러나 중남미에는 경제개발로 부터 소외된 사회부문이 광범위하게 퍼져 있고 빈곤, 실업, 소득 불평등, 범죄 등이 눈에 띠게 개선되고 있는 흔적이 보이지 않고 있다. 멕시코의 경우에는 중남미에서 두 번째로 CSR 활동이 왕성하지만, 마약범죄 감소에는 별로 영향을 주지 못했다. 페루의 경우, 자원개발업체들의 CSR 활동은 모범적이지만 지역사회 주민과 개발간의 갈등이 수그러들지 않고 있다.

\section{VII. 결론}

기업의 사회적 책임이 개도국 사회개발에 효과적이기 위해서는 몇 가지 전제가 필요하다. 첫 째, 일부 대기업이나 다국적기업뿐만 아니라 중소기업도 경쟁력을 갖추어야 사회투자 여력을 확대할 수 있다. 대기업이나 다국적기업은 이미 경쟁력이 있어 재정적 여력이 있지만 중소기업 은 생존을 목표로 하는 경우가 대부분이다. 둘째, 기업의 사회적 투자가 사회 발전의 일시적 촉 매가 되어야지 지속적으로 사회의 기업의존도를 강화해서는 기업의 경쟁력을 떨어뜨릴 위험이 높다. 셋째, 기업은 적어도 부정적 외부효과를 사회에 부담시켜서는 안 되며 모든 기업은 이를 보편적 윤리로 실천해야 한다.

중남미의 사회적 책임활동이 소외된 사회의 교육, 건강 등 소득증대에 중점을 두고 있어 자립 적 사회개발의 촉매로 작용할 것으로 보인다. 그러나 사회투자 대상이 너무나 광범위하여 대기 업이나 다국적기업만으로는 효과적으로 사회문제를 풀기는 어렵다. 개별기업의 사회투자가 사 회 체계적인 사회개발계획에 의하기 보다는 각 기업의 이해관계에 의해 이루어질 가능성이 높 다. 때문에 중앙 및 지방정부, 국제기관 및 기업이 사회개발의 청사진을 가지고 보다 체계적으 로 접근할 필요가 있다. 기업의 사회적 책임도 전문화 된 기관이 서로 분업과 협력체계를 가져 야 효율적으로 수행될 수 있을 것이다. ${ }^{31)}$

30) Zuleika Ferre, Natalia Melgar, and Mximo Rossi, "Corporate Social Responsibility in Uruguay: What Enterprises Do and What People Think about It," in The United Nations Conference on Trade and Development (UNCTAD), Corporate Social Responsibility in Latin America, United Nations, 2010. Pp. 29-60.

31) Campbell, J. L., "Why Would Corporations Behave in Socially Responsible Way? An Institutional Theory of Corporate Social Responsibility," Academy of Management Review, 32 (2007), pp. 946-967. 
지난 10 여년간 중남미에서 CSR이 빠르게 확산되고 있지만, 아직도 많은 중소기업, 특히 미등 록업체는 참여하지 못하고 있다. 통계에도 잘 잡히지 않는 미등록업체가 산재하고 있는 한 CSR 의 효과를 극대화할 수는 없다. 이미 멕시코와 브라질 등에서 미등록업체의 등록을 유도하는 프 로그램이 있다. 예를 들면, 멕시코에는 등록절차를 간소화 한 SARE Programme이 있다. 브라 질에는 세금을 감면해주는 SIMPLES Programme이 있다. 그러나 다수를 차지하고 있는 미등 록기업체가 등록되도록 국제기관이나 정부가 더 많은 지원을 할 필요가 있다. 세계은행의 2008 년 보고서에 따르면,32) 중남미 도시근로자의 $56 \%$ 가 미등록업체에서 종사하고 있고, 이들의 고 용인 반 이상이 청년이다. 또한 대기업의 경우 자연보호나 공해방지 기술을 개발하여 부정적 외 부효과를 줄이고 있지만 중소기업은 그렇지 못하다.

역설적이지만, 기업의 사회적 책임 확산을 위해서 정부와 사회는 기업이 특히 중소기업이 사 회적 비용을 줄여 사회투자 여력을 확보하도록 지원해야 한다. 브라질의 경우, 복잡한 세제와 노동규제는 고비용의 요인으로 지목되고 있다. 경영자가 고려해야 할 노동관련 규제와 비용이 변호사 없이 지켜지기기는 어렵다.

$\mathrm{CSR}$ 을 활성화하기 위해 정부가 기업에 분담금을 일률적으로 정하거나 강제하는 것은 부작용 이 많을 것이다. 베네수엘라의 경우, 차베스(Hugo Chávez) 정부는 기업의 CSR 활동을 강제하 고 있지만, 자본도피라는 부작용이 많이 나타나고 있다. 민간기업이 일정의 생산, 고용, 가격 등 의 요건을 충족하지 못하면 정부는 그 기업을 국유화하고 있다. 또한 기업은 일정 비율의 수익 을 사회를 위해 투자해야 한다. 예를 들면, 석유회사인 PDVSA는 지역사회의 교육, 의료 및 주 택 개발 등을 책임지고 있지만, 1990 년대 중반정도 세계적 우량기업이던 PDVSA는 보통기업으 로 추락하였다.

32) World Bank, Informality in Latin America, 2008. http://www.ethicalcorp.com. 